\title{
PELAKSANAAN PERATURAN MENTERI PERHUBUNGAN RI NO 18 TAHUN 2020 TENTANG PENGENDALIAN TRANSPORTASI DALAM RANGKA PENCEGAHAN COVID 19
}

\author{
(Studi Kasus Pada Perusahaan Transportasi Online Grab di Kota Surakarta)
}

Muhammad Bilal, Suharno, Nourma Dewi; Fakultas Hukum Universitas Islam Batik, Jl. KH Agus Salim No. 10 Surakarta; E-mail: bilal6136@gmail.com

\begin{abstract}
Abstrak
Covid-19 yang mempunyai tingkat penularan dan korban kematian yang tinggi menimbulkan perubahan besar bagi pola kehidupan masyarakat termasuk dalam pengelolaan transportasi online di Indonesia. Dalam pengelolaan transportasi online saat ini pemerintah telah mengeluarkan Peraturan Menteri Perhubungan Nomor 18 Tahun 2020 tentang Pengendalian Transportasi dalam Rangka Pencegahan Covid-19 (Permen). Penelitian ini bertujuan untuk mengetahui pelaksanaan dan kendala pelaksanaan Permen tersebut pada bisnis transportasi online Grab yang ada di Kota Surakarta. Penelitian ini merupakan jenis field research kualitatif, yang dilaksanakan di Perusahaan Transportasi Online Grab di Kota Surakarta dengan menggunakan pendekatan yuridis dan empiris. Hasil penelitian ini menemukan bahwa kebijakan moda transportasi online Grab di Kota Surakarta telah melakukan berbagai perubahan dalam standar operasional prosedur dalam pelaksanaan bisnis transportasi online di masa pandemi Covid19 dalam rangka pencegahan penyebaran Covid-19 di Kota Surakarta kendati masih terdapat kesadaran yang rendah bagi mitra pengemudinya.
\end{abstract}

Kata Kunci: Peraturan Menteri No. 28 Tahun 2020, Pencegahan Covid-19, Transportasi Online

\section{Abstract}

Covid-19 which has a high transmission and mortality rate, has caused major changes to the people's lifestyles, including the management of online transportation in Indonesia. In managing online transportation, the government has issued Regulation of the Minister of Transportation Number 18 of 2020 concerning Transportation Control in the Context of Prevention of Covid-19 (Permen). This study aims to determine the implementation and constraints of implementing the Permen in the Grab online transportation business in Surakarta. This research is a type of qualitative field research, which is carried out at the Grab Online Transportation Company in the city of Surakarta using a juridical and empirical approach. The results of this study found that the Grab online transportation mode policy in Surakarta has made various changes in standard operating procedures in the implementation of online transportation business during the Covid-19 pandemic in order to prevent the spread of Covid-19 in Surakarta although there is still low awareness from the driver partners.

Keywords: Ministerial Regulation No. 28 of 2020, Covid-19 Prevention, Online Transportation

\section{PENDAHULUAN}

\section{Latar Belakang}

Dunia akhir-akhir ini sedang dilanda wabah penyakit akibat Coronavirus Disease (Covid-19) a t a u virus corona yang sangat meresahkan, bahkan hampir seluruh negara di dunia terkena dampak penyebaran virus ini termasuk Indonesia. Covid-19 merupakan salah satu virus yang belakangan muncul dengan kasus pertama di Kota Wuhan Provinsi Hubei China. Virus ini mempunyai tingkat penularan yang tinggi yang dapat menular dari manusia ke manusia dan telah menyebar secara luas di China dan bahkan telah menyebar lebih dari 190 negara dan teritori lainnya (WHO, 2019), dan pada 
12 Maret 2020, WHO telah mengumumkan Covid-19 sebagai pandemi. ${ }^{1}$ Pada tanggal 5 Maret 2020, telah terdapat 634.385 kasus dan 33.106 jumlah kematian di seluruh dunia (Wu Z, McGoogan JM). Hingga sampai dengan tanggal 4 Oktober 2020 sudah mencapai 35,4 juta kasus dan 1,04 juta kasus yang meninggal, sementara di Indonesia ditetapkan sampai dengan tanggal 4 Oktober 2020 telah terdapat 307 ribu kasus dan 11.235 kasus kematian. ${ }^{2}$

Dilihat dari jumlah pertumbuhan kasus ini, Covid-19 mempunyai tingkat penyebaran yang sangat tinggi. Dampak dari penyebaran wabah penyakit ini secara drastis mempengaruhi hampir semua sektor, khususnya perekonomian di setiap negara. Semua negara di dunia menyatakan berperang melawan penyebaran virus corona yang sedang melanda. Tidak terkecuali negara Indonesia melalui berbagai kebijakan yang telah dikeluarkan oleh Pemerintah khususnya melalu Menteri Kesehatan menetapkan kebijakan dalam upaya pencegahan virus corona ini (Covid-19).

Pemerintah melalui Menteri Kesehatan menyatakan bahwa dalam rangka upaya penanggulangan dini wabah COVID-19, Menteri Kesehatan telah mengeluarkan Keputusan Menteri Kesehatan Nomor HK.01.07/MENKES /104/2020 tentang Penetapan Infeksi Novel Coronavirus (Infeksi 2019-nCoV) sebagai jenis penyakit yang dapat menimbulkan wabah dan upaya penanggulangannya. Penetapan didasari oleh pertimbangan bahwa Infeksi Novel Coronavirus (Infeksi 2019-nCoV) telah dinyatakan WHO sebagai Kedaruratan Kesehatan Masyarakat yang Meresahkan Dunia (KKMMD)/Public Health Emergency of International Concern (PHEIC). Selain itu meluasnya penyebaran COVID-19 ke berbagai negara dengan risiko penyebaran ke Indonesia terkait dengan mobilitas penduduk, memerlukan upaya penanggulangan terhadap penyakit tersebut.

Penyebaran Covid-19 yang sudah menyebar ke seluruh wilayah provinsi di Indonesia dengan jumlah kasus dan/atau jumlah kematian yang selalu meningkat dari waktu ke waktu, maka berdampak pada segala aspek seperti aspek politik, ekonomi, sosial, budaya, pertahanan dan keamanan, serta kesejahteraan masyarakat di Indonesia, sehingga Pemerintah Indonesia menetapkan kejadian ini sebagai bentuk kedaruratan kesehatan masyarat melalui Keputusan Presiden Nomor 11 Tahun 2020 tentang Penetapan Kedaruratan Kesehatan Masyarakat Covid-19. Untuk itu di Indonesia wajib dilakukan upaya penanggulangan sesuai ketentuan peraturan perundang-undangan.

Pemerintah Indonesia juga menjadikan wabah Covid-19 sebagai bencana non alam nasional mengingat penyebaran Covid-19 berdampak pada meningkatnya jumlah

\footnotetext{
${ }^{1}$ World Health Organization. WHO Director-General's opening remarks at the media briefing on COVID-19-11 March 2020 [Internet]. 2020 [updated 2020 March 11]. Available from: https://www.who.int/dg/speeches/detail/who- director-generals-opening-remarks-at-themedia-briefing-on-covid-19---11- march-2020. Diakses 5 Oktober 2020.

${ }^{2}$ World Health Organization. Coronavirus disease 2019 (COVID19) Situation Report - 70 [Internet]. WHO; 2020 [updated 2020 March 30; cited 2020 March 31]. Available from: https://www.who.int/ docs/ default -source/coronaviruse/situationreports/20200330-sitrep-70-covid-19.pdf? sfvrsn=7e0fe3f8_2. Diakses 5 Oktober 2020.
} 
korban dan kerugian harta benda, meluasnya cakupan wilayah terdampak, serta menimbulkan implikasi pada aspek sosial ekonomi yang luas di Indonesia yang ditetapkan dalam Keputusan Presiden Nomor 12 Tahun 2020 tentang Penetapan Bencana Non Alam Penyebaran Covid-19 sebagai Bencana Nasional. Melihat kondisi ini, perlu upaya serius dan peningkatan kesadaran masyarat akan pentingnya kesehatan dalam upaya mendukung pencegahan penyebaran Covid-19.

Penyebaran Covid-19 yang berdampak terhadap berbagai sektor khususnya aspek ekonomi salah satu bidang ekonomi yang terpuruk terkait dengan adanya penyebaran Covid-19 ini adalah sektor transportasi. Bisnis transportasi merupakan terkena dampak yang serius dengan adanya penyebaran Covid-19 ini. Dengan adanya kebijakan PSBB di beberapa kota besar memberikan dampak yang sangat serius bagi sektor transportasi. Dengan adanya himpauan untuk tetap di rumah "stay at home" menjadikan bisnis transportasi sempat tidak beroperasi. Selain itu adanya peraturan pemerintah yang melarang bisnis transportasi online untuk tidak mengangkut penumpang juga memberikan dampak negatif bagi sektor transportasi.

Berbagai upaya pemerintah telah dilakukan dalam rangka mengendalian penyebaran Covid-19 agar tidak semakin meluas, meskipun demikian penyebaran Covid-19 tetap meningkat penyebarannya. Kondisi ini dirasakan bahwa untuk dapan memutus rantai penyebaran Covid-19 tidak dapat dilakukan, namun yang dapat dilakukan adalah dengan mengendalian penyebarannya agar semakin meluas. Belakangan pemerintah telah mengeluarkan kebijakan "New Normal" (era baru) dimana masyarakat harus mampu untuk hidup dalam tatanan kehidupan yang baru berdampingan dengan penyebaran Covid-19 yang ada di sekitar masyarakat. Dalam kondisi ini perlunya peningkatan kesadaran masyarakat akan gerakan hidup sehat dan mengatur segala tatanan kehidupan untuk tetap patuh pada protokol kesehatan yang sudah ditetapkan.

Terkait dengan pengendalian penyebaran Covid-19 di sektor transportasi pemerintah melalui Menteri Perhubungan menetapkan Peraturan Menteri Perhubungan Nomor PM 18 Tahun 2020 tentang Pengendalian Transportasi Dalam Rangka Pencegahan Penyebaran Corona Virus Disease (Peraturan Menteri No. 28 Tahun 2020).

\section{Rumusan Masalah}

Menimbang latar belakang di atas, dalam penelitian ini peneliti bermaksud mengangkat permasalahan yang terkait dengan pelaksanaan Peraturan Menteri Perhubungan Nomor PM 18 Tahun 2020 tentang Pengendalian Transportasi Dalam Rangka Pencegahan Penyebaran Corona Virus Disease (Peraturan Menteri No. 28 Tahun 2020) khususnya pada bisnis transportasi online Grab yang ada di Kota Surakarta. 


\section{METODE PENELITIAN}

1. Jenis dan Lokasi Penelitian

Penelitian ini menggunakan jenis field research kualitatif, dengan lokasi penelitian di Perusahaan Transportasi Online Grab di Kota Surakarta. Pilihan lokasi penelitian tersebut didasarkan pada pertimbangan bahwa Grab sebagai salah satu perusahaan transportasi online yang merasakan dampak mewabahnya Covid-19 khususnya di Kota Surakarta.

2. Pendekatan Penelitian

Dalam penelitian ini menggunakan pendekatan yuridis dan empiris. Secara yuridis dengan mengkaji pelaksanaan peraturan perundangan-undangan yang berkaitan dengan pengendalian transportasi dalam rangka pencegahan Covid-19 bagi pelaku bisnis transportasi online Grab di Kota Surakarta. Secara normatif dengan cara melihat kenyataan yang ada di lapangan berkaitan dengan permasalahan yang akan diteliti yang dipandang dari sudut penerapan hukum.

3. Jenis Data

Data yang digunakan dalam penelitian ini adalah sebagai berikut:

a. Data primer adalah data yang diperoleh langsung di lokasi penelitian yaitu Perusahaan transportasi online Grab di Kota Surakarta.

b. Data sekunder adalah data yang digunakan untuk mendukung data primer yang diperoleh dari sumber tertulis.

4. Sumber Data

Sumber data yang ada dalam penelitian ini diantaranya:

a. Sumber Data Primer

Sumber data primer ini adalah hasil dari wawancara terhadap pihak-pihak pengelola transportasi online Grab di Kota Surakarta yang mengetahui kondisi riil di lapangan terkait dengan pelaksanaan Peraturan Menteri Perhubungan Nomor PM 18 Tahun 2020 tentang Pengendalian Transportasi dalam Rangka Pencegahan Covid-19 yang akan dibahas serta dokumen-dokumen yang didapat langsung dari lokasi penelitian seperti pihak manajemen Grab, mitra driver Grab dan konsumen Grab.

b. Sumber Data Sekunder

Suber data sekunder dalam penelitian ini diperoleh dari studi kepustakaan dan field research yaitu dengan menghimpun data-data dan peraturan perundang-undangan, buku-buku karya ilmiah, dan pendapat para ahli terkait dengan masalah yang dibahas untuk menjadi acauan teori dalam pembahasan lebih lanjut serta beberapa sumber hukum:

1) Bahan Hukum Primer seperti:

a) Undang-Undang Dasar Negara Republik Indonesia Tahun 1945;

b) Undang-Undang Nomor 6 Tahun 2018 tentang Karantina Kesehatan.

2) Bahan hukum sekunder seperti Peraturan Menteri Perhubungan Nomor 18

Tahun 2020 tentang Pengendalian Transportasi dalam Rangka Pencegahan Penyebaran Covid 19 (Peraturan Menteri No. 28 Tahun 2020). 
3) Bahan hukum tersier seperti peraturan perusahaan transportasi grab dalam rangka pencegahan Covid 19.

5. Teknik Pengumpulan Data

Dalam pembahasan penulisan hukum ini, diperlukan data yang cukup sebagai bahan analisis. Selanjutnya untuk menentukan data yang diperlukan, maka digunakan metode pengumpulan data sebagai berikut:

a. Wawancara, yaitu penulis mengadakan tanya jawab dengan pihak-pihak yang terkait langsung dengan masalah yang dibahas, dalam hal ini manajer operasional perusahaan transportasi online Grab di Kota Surakarta beserta para mitra pengemudi dan penumpang transportasi online Grab di Kota Surakarta.

b. Studi dokumentasi, yaitu penulis mengambil data dengan mengamati dokumen- dokumen dan arsip-arsip yang terkait dengan penelitian ini.

6. Teknik Analisis Data

Dalam penulisan ini, penulis menggunakan sistem analisis data secara kualitatif dan kemudian dipaparkan secara deskriptif. Analisis data secara kualitatif yaitu analisis data yang diperoleh melalui wawancara langsung dengan para informan yang terkait dengan pembahasan permasalahan dalam penelitian ini untuk lebih mendapatkan gambaran nyata terkait dengan pelaksanaan Peraturan Menteri No. 28 Tahun 2020 yang ada pada transportasi online Grab di Kota Surakarta.

7. Pengujian Keabsahan Data

Dalam menguji data dan materi yang disajikan, dipergunakan metode sebagai berikut:

a) Deskriptif yang pada umumnya digunakan dalam menguraikan, mengutip atau memperjelas bunyi peraturan perundang-undangan dan uraian umum.

b) Komperatif yang pada umumnya digunakan dalam membandingkan perbedaan pendapat, terutama terhadap materi yang mungkin dapat menimbulkan ketidaksepahaman serta dapat menimbulkan kerancuan.

c) Dedukatif yang pada umumnya berpedoman pada peraturan perundangundangan. 


\section{PEMBAHASAN}

A. Pelaksanaan Peraturan Menteri Perhubungan Nomor PM 18 Tahun 2020 tentang Pengendalian Transportasi dalam Rangka Pencegahan Penyebaran Covid-19 pada Bisnis Transportasi Online Grab yang Ada di Kota Surakarta

Penetapan Peraturan Menteri Perhubungan Nomor PM 18 Tahun 2020 tentang Pengendalian Trasportasi dalam Rangka Pencegahan Penyebaran Covid-19 (Peraturan Menteri No. 28 Tahun 2020) sebagai bentuk dari pelaksanaan kebijakan pemerintah di bidang transportasi terkait dengan munculnya wabah virus Covid-19 yang telah ditetapkan sebagai kondisi kedaruratan kesehatan masyarakat Covid-19 yang ditetapkan melalui Keputusan Presiden Republik Indonesia Nomor 11 Tahun 2020 dan menyikapi Peraturan Pemerintah Nomor 21 Tahun 2020 tentang Pelaksanaan Pembatasan Sosial Berskala Besar (PSBB) dalam rangka percepatan penanganan Covid-19.

Dalam penelitian ini peneliti mengambil fokus penelitian terkait dengan pelaksanaan Peraturan Menteri No. 28 Tahun 2020 yang terdapat pada bisnis transportasi umum online Grab yang ada di Kota Surakarta. Kondisi pandemi Covid-19 yang terjadi bagi Grab merupakan sebuah dilema mengingat di satu sisi perlu menyikapi adanya pelaksanaan PSBB yang terjadi di kota-kota besar untuk membatasi aktivitas dan lebih banyak tinggal di rumah, di sisi lain Grab juga harus memikirkan kesejahteraan para mitra driver yang juga membutuhkan pendapatan untuk memenuhi kebutuhan ekonomi mereka. Dalam kondisi yang sulit aktivitas bisnis Grab harus tetap beroperasi mengingat hal ini menyangkut masalah nasib para mitra driver yang sangat menggantungkan hidupnya pada Grab.

Melihat kondisi ini Grab menetapkan berbagai kebijakan baru terkait dengan operasional Grab. Grab tetap memprioritaskan pada keselamatan dan kesejahteraan komunitas Grab agar para mitra driver tetap dapat beroperasi dengan semaksimal mungkin dan tetap dapat menghindarkan penyebaran Covid-19.3 Layanan Grab yang berupa pengiriman barang, Grab Mart, dan transportasi tetapi beroperasi untuk melayani kebutuhan masyarakat di Kota Surakarta dengan tetap menyediakan layanan harian yang terpenting dengan cara yang paling aman. Grab juga selalu berupaya untuk melindungi kesejahteraan para mitra driver serta melindungi kesehatan dan keselamatan mitra driver dengan melakukan tindakan inisiatif seperti: ${ }^{4}$

1. Bagi Penumpang

a. Grab menganjurkan penumpang memakai alat pembayaran non-tunai seperti OVO untuk mengurangi kontak fisik.

b. Grab mewajibkan penumpang memakai masker ketika di luar rumah.

c. Layanan GrabBike dinonaktifkan sementara karena adanya pelaksanaan PSBB yang ditetapkan oleh pemerintah kecuali penggunaan GrabBike khusus untuk mengantarkan ke dan dari RS, pasar, supermarket sesuai prosedur atau protokol

\footnotetext{
3 Wawancara dengan Agung DH selaku Manajemen Operasional Grab Surakarta, Kamis, 1 Oktober 2020. Pukul 13.00 WIB.

${ }^{4}$ Dokumen Kebijakan Operasional Grab di Masa Pandemi Covid-19.
} 
kesehatan selama pandemi. ${ }^{5}$

1) Layanan GrabBike masih dapat melayani penumpang di sekitar kota-kota besar di seluruh Inodnesia.

2) Layanan GrabCar yang tetap melayani penumpang.

2. Bagi Pengguna Layanan GrabFood, GrabMart, GrabFresh dan GrabExpress

Bagi para pengguna layanan Grab seperti GrabFood, GrabMart, GrabFresh dan GrabExpress, maka Grab menetapkan kebijakan seperti:

a. Meluncurkan pengantaran atau pengiriman tanpa kontak untuk keselamatan mitra dan pelanggan.

b. Mensosialisasikan pelaporan suhu tubuh setiap harinya bagi mitra pengantaran dan pengemudi Grab. Jika mitra pengantaran dan pengemudi menunjukkan gejala seperti deman, suhu tubuh tinggi, pilek, dan batuk maka platform akan ditangguhkan sementara dan diberi bantuan keuangan.

c. Bekerjasama dengan mitra restoran dan merchant untuk peningkatan standar keamanan terpadu untuk layanan pengantaran makanan yang sesuai prosedur kebersihan baik untuk penanganan dan pengemasan makanan. ${ }^{6}$

3. Bagi Mitra Pengemudi dan Pengantaran

Bagi mitra driver/pengemudi Grab menetapkan kebijakan diantaranya sebagai berikut:

a. Menyediakan masker dan hand sanitizer untuk mitra pengemudi GrabBike dan GrabCar. Grab terus mencari pasokan lebih banyak di tengah kekurangan global saat ini.

b. Menyiapkan stasiun desinfeksi dan pembersihan mobil di berbagai kota untuk menyanitasi GrabBike dan GrabCar

c. Grab telah meminta semua mitra pengiriman untuk mengenakan masker, menggunakan pembersih tangan yang disediakan oleh merchant, dan mematuhi langkah-langkah kesehatan dan keselamatan di tempat merchant.

d. Selain layanan GrabFood, GrabExpress dan GrabFresh yang telah ada, kami telah memperluas layanan GrabMart, layanan pengiriman kebutuhan harian milik Grab, dan layanan concierge on-demand milik Grab, GrabExpress Nalangin di banyak kota di Indonesia. Kelima layanan ini akan membantu pelanggan untuk tetap berada di rumah sebagai upaya untuk menghentikan penyebaran virus. Layanan ini juga akan memberikan mitra pengemudi kami, baik GrabBike maupun GrabCar, peluang untuk mendapatkan penghasilan lebih banyak melalui Grab. ${ }^{7}$

e. Grab telah meluncurkan Program Bantuan Mitra, GrabCare, yang menyediakan bantuan finansial dan medis bagi mitra pengemudi dan mitra pengantaran yang paling terdampak Covid-19:

${ }^{5} \mathrm{Ibid}$.

${ }^{6}$ Ibid.

${ }^{7}$ Ibid. 
1) Mitra pengemudi GrabBike dan GrabCar juga akan menerima bantuan keuangan sebesar Rp 1,5 juta (untuk GrabBike) dan Rp 3 Juta (untuk GrabCar) apabila dinyatakan positif Covid-19 dan dimandatkan untuk menjalani karantina. Semoga bantuan ini dapat memberikan ketenangan terkait tanggungan kendaraan dan kebutuhan hidup lainnya selama masa karantina dan penyembuhan.

2) Untuk mendukung program relaksasi keuangan pemerintah, kami bekerja sama dengan TPI, sebuah perusahaan angkutan sewa khusus (rental kendaraan), telah menjalankan program bagi mitra pengemudi GrabCar melalui penundaan biaya rental mobil hingga dua (2) bulan ke depan serta pemberian dana tunai sebagai bagian dari program loyalitas mitra yang tergabung dalam TPI.

3) Kami juga sedang membantu Asosiasi Perusahaan Pembiayaan Indonesia (APPI) yang difasilitasi oleh OJK mendata debitur leasing yang merupakan mitra-pengemudi GrabBike dan GrabCar serta mereka yang terkena dampak dari pandemi ini sesuai dengan kriteria dan persyaratan yang ditetapkan oleh OJK untuk pengajuan restrukturisasi pinjaman secara kolektif. 8

4. Bagi Mitra Merchant dan Restoran

Kebijakan Grab bagi mitra merchant dan restoran di masa pandemi diantaranya sebagai berikut:

a. Grab telah berkolaborasi dengan mitra merchant dan restoran untuk meningkatkan prosedur kebersihan yang menyeluruh mulai dari proses penyiapan dan pengemasan makanan yang benar hingga proses pengiriman yang aman.

b. Grab telah mengimplementasikan 'Kartu Keterangan Pengiriman GrabFood' bagi mitra merchant yang memuat informasi tanggal, waktu, nama, dan suhu tubuh karyawan yang menyiapkan makanan semua pesanan GrabFood. Jika salah satu mitra pengantaran menunjukkan gejala seperti suhu tubuh tinggi, demam, pilek, dan batuk, mitra merchant dapat melaporkannya kepada tim layanan pelanggan Grab dan mitra pengantaran pengganti akan ditugaskan untuk mengirimkan pesanan tersebut.

c. Grab telah menyediakan lebih dari 2.000 termometer tembak digital untuk mitra merchant terpilih. ${ }^{9}$

Kebijakan yang ditetapkan oleh Grab bagi mitra restoran, Program Dukungan Merchant Grab akan membantu diantaranya sebagai berikut:

a. Menghasilkan pendapatan tambahan melalui peningkatan visibilitas dalam aplikasi, promosi khusus, dan kategori khusus untuk restoran lokal.

b. Mengurangi biaya operasional melalui program cashback untuk bahan makanan umum dan diskon pada kemasan makanan.

Dalam masa sulit ini, Grab juga berupaya untuk tetap berkomitmen dalam

${ }^{9}$ Ibid. 
melayani dan mendukung komunitas mitra pengemudi, pengantaran, merchant dan pelanggan kami sebaik mungkin. Dengan dukungan satu sama lain, kami yakin kita dapat menghadapi hal ini bersama. ${ }^{10}$

Selain itu Grab melalui ketentuan dari kantor pusat yang diungkapkan oleh Managing Director Grab Indonesia, terkait dengan kondisi Covid-19 yang sedang terjadi seperti saat ini, menerangkan bahwa dalam menghadapi situasi terburuk dampak Covid-19 Grab menyadari pentingnya menjaga kualitas sanitasi dan keamanan berkendara bagi pelanggannya selama masa pandemi Covid-19 ini. Upaya ini diperkuat dengan edukasi maupun aksi lini transportasi Grab baik secara offline maupun online. ${ }^{11}$ Berdasarkan hasil pernyataan tersebut, mulai tanggal 23 Maret 2020 Grab telah mengeluarkan program GrabHealth powered by GoodDoctor yang juga telah dipercaya oleh Kementerian Kesehatan untuk melaksanakan screening Covid-19 resmi via telekonsultasi. Grab menyadari akan pentingnya untuk memperkuat amanat tersebut dengan menyiapkan armada luar biasa agar upaya penanganan darurat Covid-19 juga dapat tetap berjalan secara fisik.

Grab juga telah bersiap siaga untuk menyebarkan armada khusus bagi garda terdepan masyarakat Indonesia dalam penanganan Covid-19, terutama bagi mereka yang memiliki profesi yang tetap bekerja di masa kritis seperti masa pandemi saat ini, seperti: tenaga medis, media, militer dan sebagainya. Armada Grab akah dikhususkan untuk mendukung mobilitas para tenaga medis yang berjuang melawan pandemi Covid19.12

Selain itu Grab juga bekerjasama dengan Kementerian Kesehatan serta bermitra dengan Rumah Sakit rujukan Covid-19 dengan mengeluarkan aplikasi GrabNow yang dialokasikan bagi tenaga medis yang memerlukan mobilitas, stasiun desinfektan akan dipersiapkan di rumah sakit terpilih untuk memastikan sterlisasi kendaraan sebelum memasuki area kritis. Terdapat sebanyak 1.000 mobil GrabCar dan 1.000 GrabBike di seluruh Indonesia telah disiagakan agar tenaga medis Indonesia bisa tetap bisa menjaga tugas mulianya tanpa perlu pusing karena sarana mobilisasi sehari-hari. Grab Indonesia juga telah memasuki tahap akhir perjanjian kerjasama untuk mengimplementasikan kerjasama ini dengan Kementerian Pariwisata dan Kreatif Republik Indonesia. ${ }^{13}$

Beberapa kesiapan Grab dalam menanggapi kondisi pandemi Covid-19 seperti saat ini diantaranya adalah:

1. Kesiapan Armada

a. Kesiapan armada Grab selalu memperhatikan dari segi pencegahan penularan Virus Covid-19 dengan menggunakan partisi plastik antar penumpang dengan pengemudi.

10 Ibid.

11 Pernyataan Neneng Goenadi, selaku Managing Director Grab Indonesia, tanggal 2 April 2020. http://www.grab.com/id/press//consumers-drivers/lini-transportasi-grabberjibaku-melawan-covid-19/.

12 Ibid.

${ }^{13}$ Ibid. 
b. Mitra pengemudi GrabCar dan GrabBike juga dilengkapi dengan Alat Pelindung Diri (APD) seperti masker dan sarung tangan.

c. Grab juga telah mempersiapkan goggles, masker, dan pelindung sepatu apabila situasi penyebaran virus semakin memburuk.

d. Grab Indonesia siap membantu ekspansi armada khusus ini ke puluhan rumah sakit rujukan untuk mendukung pemerintah dalam penanganan Covid-19.

e. Armada khusus ini akan diuji coba ke beberapa rumah sakit rujukan di Jakarta. Grab Indonesia siap membantu ekspansi armada khusus ini ke puluhan rumah sakit rujukan (dan rumah sakit umum lainnya) untuk mendukung pemerintah dalam penanganan Covid-19.

2. Manfaat Armada

a. Armada khusus lini transportasi Grab ini dapat membantu kinerja dan kesiapan tenaga medis dalam pengantaran staf medis, hasil laboratorium dan obat-obatan.

b. Untuk memastikan rapid testing dijalankan secara sigap di seluruh Indonesia, lini transportasi Grab juga dapat membantu mobilisasi tenaga medis menuju berbagai lokasi puskesmas, rumah sakit, dan klinik.

c. Inisiatif ini telah disambut baik oleh pemerintah daerah di Indonesia dan Grab berkomitmen untuk memastikan pelaksanannya.

3. Fitur Digital

a. Dogotalisasi dibutuhkan dalam menanggapi situasi krisis untuk memastikan operasional secara fisik di rumah sakit dapat berjalan dengan aman maka hal ini dapat ditanggapi dengan platform Grab For Business.

b. Para petugas medis akan mendapatkan kemudahan pemesanan transportasi armada luar biasa Grab dengan fitur concierge (layanan pemesanan transportasi memalui portal) yang dibantu oleh admin rumah sakit.

c. Fitur ini juga dapat dipergunakan bagi para pasien yang sedang membutuhkan mobilisasi dari atau ke rumah sakit untuk menghindari penumpukan massa di lokasi.

d. Pasien dapat terus melanjutkan konsultasi kesehatan dengan GrabHealth powered by GoodDoctor dan terintegrasi dengan layanan pemesanan obat dengan Grab Express web booking. ${ }^{14}$

Dalam menunjang kinerja mitra pengemudi pada program di atas, kegiatan lini transportasi lainnya tetap harus berjalan normal dengan perhatian pada kebersihan ekstra. Para mitra pengemudi Grab yang pantang mundur terus tetap berupaya memberikan pelayanan mereka yang terbaik dan Grab Indonesia telah membekali para mitra pengemudi dengan berbagai penunjang kegiatan seperti:

1. Program Grab Benefit yang menyediakan toolkit Covid-19 yang terdiri ari masker, desinfektan, hand sanitizer, dan juga edukasi preventif bagi penumpang berbentuk stiker mobil. Saat ini lebih dari 3.000 paket telah dimanfaatkan oleh mitra pengemudi Grab.

14 Ibid. 
2. Pembangunan stasiun sterilisasi dan pembersihan mobil di 1 Grab Excellence Center dan 4 Grab Driver Center di seluruh Jabodetabek yang dipergunakan oleh lebih dari 20.000 mitra pengemudi GrabCarPlus. Penyediaan sarana ini akan diperluas sehingga mencapai 10 kota di seluruh Indonesia.

3. Pencucian helm dan jake mitra pengemudi GrabBike dilakukan dihampir 20 lokasi di Pulau Jawa untuk memastikan sanitasi pengemudi maupun penumpang.

4. Penerapan standar operasional pelayanan GrabCar dan GrabBike yang menyesuaikan situasi pandemi Covid-19 dengan standar kebersihan dan keamanan yang lebih tinggi untuk menhindari penyebaran virus pada saat berkendara yang mencakup:

a. Standar kebersihan dan kondisi kesehatan sebelum perjalanan.

b. Pelayanan kepada penumpang yang lebih peka terhadap kesehatan penumpang sambil tetap menjaga keramahan.

c. Upaya kebersihan dan sterilisasi menyeluruh secara mandiri setelah perjalanan.

5. Seluruh upaya ini disosialisasikan secara menyeluruh tanpa kontak lansungan (contactless education) melali platform online seperti aplikasi Mitra Pengemudi, media sosial, platform chat dan live streaming. 15

Pada dasarnya kebijakan yang dilakukan oleh Grab di tengah kondisi pandemi Covid-19 dalam upaya mencegah penyebaran Covid-19 sesuai dengan ketentuan yang diatur dalam Peraturan Menteri No. 28 Tahun 2020. Sesuai dengan ketentuan Pasal 3 yang menyatakan bahwa pengendalian transportasi untuk seluruh wilayah yang dilakukan terhadap transportasi menyangkut penumpang dan barang, sesuai dengan yang dilakukan oleh Grab yang mengangkut penumpang dan barang dalam operasional bisnisnya juga telah melakukan berbagai kebijakan yang disesuaikan dengan standar operasional yang baru yang menyesuaikan kondisi pandemi Covid-19. Seperti yang telah dijelaskan di atas, dimana Grab telah melakukan berbagai upaya dalam mengatasi penyebaran Covid-19 seperti dengan tetap menjaga protokol kesehatan dengan wajib memakai masker (baik mitra pengemudi maupun penumpang), menjaga jarak yang dilakukan dengan memberikan batas partikel plastik antara mitra pengemudi dan penumpang baik pada GrabCar maupun GrabBike, selalu memakai APD bagi mitra pengemudi seperti masker dan sarung tangan, melakukan pembersian rutin baik armada maupun jaket untuk mintra pengemudi.

Kebijakan-kebijakan yang dilakukan oleh Grab di masa pandemi ini pada dasarnya telah dilakukan sesuai dengan ketentuan-ketentuan Peraturan Menteri No. 28 Tahun 2020 terkait dengan kaidah-kaidah dalam pengendalian penyebaran Covid-19 di bidang transportasi umum seperti kewajiban memakai masker, menjaga jarak, dan menjaga sanitasi dan sterilisasi bagi para mitra pengemudi dan penumpang dengan menyediakan desinfektan dan hand sanitazer pada toolkit armadanya serta memastikan mitra pengemudi dan penumpang dalam kondisi yang sehat serta membatasi kapasita jumlah penumpang bagi GrabCar. Selain itu Grab juga telah bekerjasama dengan pemerintah melalui Kementerian Kesehatan untuk mendukung aktivitas vital seperti tenaga medis

${ }^{15}$ Ibid. 
pada khususnya di masa pandemi Covid-19 seperti sekarang ini. Bahkan Grab juga berupaya untuk menggalang donasi melalui aplikasi Grab Peduli Covid untuk mengajak mitra pengguna Grab untuk melakukan donasi untuk menyumbang untuk ketersediaan APD bagi para tenaga medis.

Berdasarkan hasil penelitian ini dapat diketahui bahwa Grab selama masa pandemi telah melakukan perubahan moda transportasi umum yang telah disesuaikan dengan kondisi di masa pandemi Covid-19 dalam rangka menghindari penyebaran Covid-19. Grab juga berupaya untuk tepat menjaga kelangsungan perekonomian para mitra pengemudi. Grab juga merupakan moda transportasi umum yang sesuai dengan protokol kesehatan yang juga telah membantu program pemerintah dalam menyediakan armada guna mendukung aktivitas vital di masa pandemin khususnya bagi para tenaga medis dan pekerja vital yang lainnya agar aktivitas masyarakat tetap dapat berjalan sehingga perekonomian juga tetap bisa berjalan.

\section{B. Kendala dalam Pelaksanaan Peraturan Menteri No. 28 Tahun 2020 tentang Pengendalian Transportasi dalam Rangka Pencegahan Penyebaran Covid-19 pada Bisnis Transportasi Online Grab yang Ada di Kota Surakarta}

Berbagai kebijakan dan program serta standar operasional yang telah ditetapkan oleh Grab dalam aktivitas bisnisnya agar tepat dapat berjalan di masa pandemi Covid-19 seperti saat ini, serta dapat mendukung program pemerintah dalam mengatasi penyebaran Covid-19 melalui penerapan moda transportasi yang sesuai di masa pandemi Covid-19 sebenarnya telah dilakukan berbagai upaya seperti yang telah dijelaskan sebelumnya. Meskipun berbagai uupaya terkait dengan pencegan terjadinya penyebaran Covid-10 yang telah dilakukan oleh Grab namun dalam pelaksanaannya juga masih terhadap berbagai hambatan dan kendala yang terjadi di lapangan.

Beberapa kendala yang masih dihadapati dalam pelaksanaan kebijakan penyebaran Covid-19 pada moda transportas online seperti Grab antara lain adalah:

1. Masih terdapat kesadaran yang rendah bagi mitra pengemudi yang tidak patuh terhadap ketentuan yang telah ditetapkan oleh perusahaan sehingga melanggar dalam pelaksanaan strandar operasional di masa pandemi Covid-19 seperti masih terdapat mitra pengemudi yang tidak memakai APD seperti masker dan sarung tangan yang sebenarnya hal ini akan membahayakan dirinya sendiri, karena resiko untuk tertular Covid-19 akan lebih besar. Sehingga dalam kondisi seperti ini kesadaran mitra pengemudi Grab sangat dibutuhkan, untuk itu dalam hal ini upaya menigkatkan kesadaran bagi para mitra pengemudi Grab harus selalu ditingkatkan. Upaya ini dapat dilakukan dengan memberikan edukasi kepada mitra pengemudi terkait dengan arti pentingnya menjaga kebersihan dan kesahatan dan menjalankan protokol kesehatan selama bekerja dan memberikan edukasi terkait dengan penyebaran Covid-19 seperti: menjelaskan bahwa Covid-19 merupakan virus yang mempunyai tingkat penularan yang tinggi dan mematikan, kita sebagai orang yang bekerja dengan berinteraksi dengan banyak orang, kita tidak tahu bahwa kita membawa virus atau tidak, dan virus 
ini berbahaya bagi orang yang ada di sekitar kita, apabila kita membawa virus, maka akan dapat menularkannya kepada keluarga atau orang-orang yang disekitar kita maka hal ini akan dapat membahayakan bagi diri kita, keluarga dan orang yang ada di sekitar kita maka perlunya kesadaran untuk berperilaku bersih dan sehat serta menjaga protokol kesehatan agar dapat terhindar dari virus ini.

2. Mitra pengemudi merupakan elemen beresiko untuk tertular Covid-19 dalam bisnis transportasi online seperti Grab, mengingat seringkali mitra pengemudi juga tidak mengetahui kondisi kesehatan para penumpangnya. Tidak seperti moda transportasi yang lain seperti pesawat terbang yang memberlakukan tes swab sebelum menggunakan moda transportasi tersebut, sehingga diketahui kodisi para penumpang sebelum menggunakan transportasi tersebut. Mengingat kondisi ini maka yang terpenting khususnya bagi para mitra pengemudi Grab kesadaran berperilaku bersih dan tetap menjalankan protokol kesehatan secara ketat merupakan salah satu upaya untuk pencegahan penyebaran Covid-19. Alangkah lebih baik apabila sebelum menggunakan moda transportasi online seperti Grab ini sebelum penumpang menggunakan jasa transportasi ini para mitra pengemudi Grab juga dilengkapi dengan alat pendeteksi suhu tubuh sehingga dapat lebih mengetahui kondisi kesehatan calon penumpang.

3. Minimnya pengendalian dalam pelaksanaan prosedur operasional pada moda transportasi online seperti Grab. Perusahaan tidak dapat memantau bagaimana pelaksanaan protokol kesehatan bagi setiap mitra pengemudi di lapangan, sehingga tidak dapat memastikan bahwa protokol kesehatan tersebut telah dilakukan dengan baik apa belum. Semua lebih tergantung pada kesadaran para mitra pengemudi. Adakalanya mendapatkan penumpang tidak mempunyai kesadaran akan protokol kesehatan, dan mitra pengemudi tidak mampu berbuat apa-apa untuk menolaknya. Perlu adanya sistem pengawasan yang lebih ketat dan adanya kebijakan bagi para pengemudi untuk dapat menolak calon penumpang yang tidak mau memenuhi ketentuan dalam pelaksanaan protokol kesehatan.

\section{PENUTUP}

Kebijakan moda transportasi online Grab di Kota Surakarta pada dasarnya telah melakukan berbagai perubahan dalam standar operasional prosedur dalam pelaksanaan bisnis transportasi online di masa pandemi Covid-19 dalam rangka pencegahan penyebaran Covid-19 di Kota Surakarta. Kebijakan dan prosedur yang dilakukan oleh Grab di Kota Surakartapada dasarnya telah sesuai dengan ketentuan Peraturan Menteri Perhubungan Republik Indonesia Nomor PM 18 Tahun 2020 tentang Pengendalian Transportasi dalam Rangka Pencegahan Penyebaran Covid-19 bahkan Grab pusat juga telah melakukan berbagai kerjasama dengan Kementrian Kesehatan dalam upaya menyediakan transportasi untuk kebutuhan vital di masa pandemi Covid-19 seperti bagi para tenaga medis. Kendala yang dihadapi oleh moda transportas online Grab dalam pencegahan penyebaran Covid-19 diantaranya adalah masih terdapat kesadaran yang rendah bagi mitra pengemudi yang tidak patuh terhadap ketentuan yang telah 
ditetapkan oleh perusahaan sehingga melanggar dalam pelaksanaan strandar operasional di masa pandemi Covid-19, mitra pengemudi merupakan elemen beresiko untuk tertular Covid-19 dalam bisnis transportasi online seperti Grab, mengingat seringkali mitra pengemudi juga tidak mengetahui kondisi kesehatan para penumpangnya dan minimnya pengendalian dalam pelaksanaan prosedur operasional pada moda transportasi online seperti Grab.

Berdasarkan hasil penelitian di atas, peneliti menyarakan 3 (tiga) hal. Pertama, perlunya peningkatan kesadaran mitra pengemudi Grab, upaya ini dapat dilakukan dengan memberikan edukasi kepada mitra pengemudi terkait dengan arti pentingnya menjaga kebersihan dan kesahatan dan menjalankan protokol kesehatan selama bekerja dan memberikan edukasi terkait dengan penyebaran Covid-19. Kedua, mengingat seringkali mitra pengemudi juga tidak mengetahui kondisi kesehatan para penumpangnya, dalam kondisi ini maka yang terpenting khususnya bagi para mitra pengemudi Grab kesadaran berperilaku bersih dan tetap menjalankan protokol kesehatan secara ketat merupakan salah satu upaya untuk pencegahan penyebaran Covid-19. Dan ketiga, perlu adanya sistem pengawasan yang lebih ketat dan adanya kebijakan bagi para pengemudi untuk dapat menolak calon penumpang yang tidak mau memenuhi ketentuan dalam pelaksanaan protokol kesehatan.

\section{DAFTAR PUSTAKA}

Andika Wijaya. (2009). Aspek Hukum Bisnis Transportasi Jalan Online.

Anggraini, Dini. (2013). "Studi tentang Perilaku Pengendara Kendaraan Bermotor di Kota Samarinda". eJournal Sosiatri-Sosiologi, 1.1.

Barda Nawawi Arief. (2013). Kapita Selekta Hukum Pidana, Cetakan Ketiga, Bandung: Citra Aditya.

Dokumen Kebijakan Operasional Grab di Masa Pandemi Covid-19.

Freddy Rangkuti. (2006). Measuring Customer Satisfaction, Teknik Mengukur dan Strategi

Meningkatkan Kepuasan Pelanggan Plus Analisis Kasus PLN-JP, Jakarta: PT Gramedia Pustaka Utama.

http://www.grab.com/id/press//drivers/lini-transportasi-grab-berjibaku-melawan-

covid-19/. Diakses, 20 November 2020.

http:/ / www.ojekindonesia.net/2016/09/manfaat-yang-kitadapat- dengan-adanya.html. Idris, Zilhardi. (Juli 2009). Kajian "Tingkat Kepuasan" Pengguna Angkutan Umum di DIY.

Dinamika Teknik Sipil, Volume 9, Nomor 2.

Ismawan, Dian Ranu, and Aminah Suradi. (2016). "Perlindungan Hukum terhadap Konsumen atas Penggunaan Taksi Uber Ditinjau dari UU No 8 Tahun 1999 tentang Perlindungan Konsumen". Diponegoro Law Journal, 5.2.

Jimly Ashidiqqie dan M. Ali Safa'at. (2012). Teori Hans Kelsen tentang Hukum. Cetakan Kedua. Jakarta: Konstitusi Press.

Juli Rarnawati dan Retno Indah Hernawati. (2016). Dasar-Dasar Perpajakan, Yogyakarta: Deepublish.

Keputusan Menteri Kesehatan Republik Indonesia Nomor 
HK.01.07/Menkes/413/2020 tentang Pedoman Pencegahan dan Pengendalian Corona Virus Disease 2019 (Covid-19).

Marcus Priyo Gunarto. (2011). Kriminalisasi dan Penalisasi dalam Rangka Fungsionalisasi Perda dan Retribusi, Program Doktor Ilmu Hukum Universitas Diponegoro Semarang. Mardalis. (1995). Metode Penelitian Suatu Pendekatan Proposal, Cet V: Ed 1: Bumi Aksara.

Moeljatno. (1983). Asas- Asas Hukum Pidana. Jakarta : Rineka Cipta.

Neneng Goenadi. (2020). Lini Transportasi Grab Berjibaku Melawan Covid-19.

Peraturan Menteri Perhubungan Republik Indonesia Nomor PM 18 Tahun 2020 tentang Pengendalian Transportasi dalam Rangka Pencegahan Covid-19.

Peraturan Menteri Perhubungan Republik Indonesia Nomor PM 41 Tahun 2020 tentang Perubahan Peraturan Menteri Perhubungan Republik Indonesia Nomor PM 18 Tahun 2020 tentang Pengendalian Transportasi dalam Rangka Pencegahan Covid-19.

Pratama, Geistiar Yoga, and Aminah Suradi. (2016). “Perlindungan Hukum terhadap Data Pribadi Pengguna Jasa Transportasi Online dari Tindakan Penyalahgunaan Pihak Penyedia Jasa Berdasarkan Undang-Undang Nomor 8 Tahun 1999 tentang Perlindungan Konsumen", Diponegoro Law Journal, 5.3.

Raida L Tobing, dkk. (2011). (Hasil Penelitian). Efektivitas Undang-Undang Monrey Loundering. Badan Pembinaan Hukum Nasional. Kementrian Hukum dan HAM RI, Jakarta.

Salim, H.S dan Erlis Septiana Nurbani. (2013). Penerapan Teori Hukum pada Tesis dan Disertasi, Edisi Pertama, Cetakan Kesatu, Jakarta: Rajawali Press.

Septanto, Henri. (2016). Ekonomi Kreatif dan Inovatif Berbasis TIK ala Gojek dan Grabbike. Bina Insani ICT Journal, 3.1.

Setiani, Baiq. (2012). "Prinsip-Prinsip Pokok Pengelolaan Jasa Transportasi Udara".

Setiani, Baiq. (2015). "Prinsip-Prinsip Pokok Pengelolaan Jasa Transportasi Udara", Jurnal Ilmiah Widya, 3.2.

Soerjono Soekanto. (1985). Efektivitas Hukum dan Peranan Saksi. Bandung: Remaja Karya.

Soerjono Soekanto. (1996). Sosiologi Suatu Pengantar, Bandung: Rajawali Pers.

Undang-Undang Nomor 19 Tahun 2016 tentang Informasi dan Transaksi Elektronik

Undang-Undang RI No. 14 Tahun 1992 tentang Lalu-Lintas dan Angkutan Jalan

Utami, Setyaningsih Sri. (2012). “Analisis Faktor-faktor yang Mempengaruhi Kepuasan Konsumen dalam Mempergunakan Jasa Transportasi PT. Solo Central Taxi di Surakarta", Ekonomi dan Kewirausahaan, 9.1. 